\title{
Microstructure, Mechanical and Electrochemical Evaluation of Dissimilar low Ni SS and 304 SS using Different Filler Materials
}

\author{
Ankur V. Bansod ${ }^{a, b *}{ }^{\oplus}$, Awanikumar P. Patil ${ }^{b}$, Jagesvar Verma ${ }^{c}$, Sourabh Shukla ${ }^{b}$ \\ ${ }^{a}$ Department of Mechanical Engineering, Vel Tech Rangarajan Dr.Sagunthala R\&D Institute of Science \\ and Technology, Avadi, Chennai, 600062, India. \\ ${ }^{b}$ Department of Metallurgical and Materials Engineering, Visvesvaraya National Institute of Technology \\ (VNIT), Nagpur, 440010, India. \\ 'Department of Mechanical Engineering, Lovely Professional University, Jalandhar, Punjab-144411, \\ India.
}

Received: February 17, 2017; Revised: August 16, 2018; Accepted: October 19, 2018

\begin{abstract}
This study investigates the effect of dissimilar metal welding of low nickel stainless steel (SS) and 304 SS employing tungsten inert gas (TIG) welding process by using three different filler materials (316L, 308L and 310 SS). Microstructural, mechanical properties and corrosion behavior in 3.5\% $\mathrm{NaCl}$ solution was studied. The microstructural investigation revealed the formation of $\delta$-ferrite and $\gamma$-austenite in the weld (welded by $316 \mathrm{~L}$ and $308 \mathrm{~L}$ filler). The Higher $\delta$-ferrite content was found more in $316 \mathrm{~L}$ weld zone. Whereas samples welded by $310 \mathrm{SS}$ filler showed the columnar structure in the weld zone. Relatively wider heat affected zone (HAZ) was measured on Cr-Mn SS side as compared to 304 SS side. Impact fracture surface of all the welded samples exhibited dimple appearance. Corrosion studies showed better pitting corrosion resistance in 316L SS welded sample due to the beneficial effect of $\delta$-ferrite and also the addition of molybdenum (Mo). Electrochemical impedance spectroscopy (EIS) revealed higher polarization resistance $\left(\mathrm{R}_{\mathrm{p}}\right)$ in $316 \mathrm{~L} \mathrm{SS}$ as compared to other fillers. Galvanic current density was found to be higher in Cr-Mn SS as compared to 304 SS when coupled with different welded samples.
\end{abstract}

Keywords: Low nickel austenitic stainless steel (Cr-Mn SS), Heat affected zone (HAZ), Pitting corrosion, EIS, Galvanic current.

\section{Introduction}

Austenitic stainless steels (ASS's) are being utilized in most of the industrial domains such as piping, pressure vessels and structural sectors. These steels are extensively used due to their excellent mechanical properties, non-magnetic and high corrosion resistance owing to its austenitic phase present in the matrix ${ }^{1,2}$. The ASS's constitute $18 \%$ chromium $(\mathrm{Cr})$ and $8 \%$ nickel $(\mathrm{Ni})$ (i.e. 300 series $\mathrm{SS}$ ) in the alloying element which provides better corrosion resistance due to its ability to form a passive film (mainly $\mathrm{Cr}_{2} \mathrm{O}_{3}$ ) over the surface ${ }^{3,4}$. Generally, Ni is added in this SS's to stabilize the austenitic structure, enlarge the $\gamma$ phase and helps in the corrosion resistance to some extent ${ }^{5}$. Recent development in the ASS's leads to the addition of manganese (Mn) and nitrogen $(\mathrm{N})$ which further stabilizes the austenitic structure. Fluctuating prices of $\mathrm{Ni}$ in the international market had caused the attention of suppliers and buyers to search for economical and reliable steels. The new series of stainless steels that has evoked the greater attention known as the 200 series or Cr-Mn SS or low Ni SS. The addition of Mn in the 200 series SS has reduced the consumption of $\mathrm{Ni}$ as the prime alloying element in $\mathrm{SS}^{6,7,8}$.

*e-mail: ankur.1754@gmail.com
In the fabrication of components of non-magnetic ASS's, welding is the most suitable and versatile joining process. Welding is used widely due to its low price and producing a high-quality joints ${ }^{9}$. Joining of dissimilar metal in industries is highly useful and cost effective in the moderate corrosive environment. Also, during welding, selection of proper filler or electrodes is an important parameter to achieve desired properties in the weld. The defects like solidification cracking, porosity, weldability in the weld metal can be minimized by selecting proper electrode ${ }^{10,11}$. It was reported that small amount of delta $(\delta)$ ferrite in the weld zone helps in overcoming the above defects ${ }^{12}$. The amount of ferrite content in the weld helps in determining the service requirement for the fabricated components. Joining of dissimilar ASS is a complex phenomenon as it may affect the dilution and can cause solidification cracking in the weldment. In joining for dissimilar austenitic SS, another major problem associated is hot cracking ${ }^{13}$, hence as a measure to avoid hot cracking filler with lesser impurities (S, P) should be used ${ }^{14}$. C. Ludin investigated on the problems associated with hot cracking and observed that $\mathrm{Mn}$ and Mo in the weld help in reducing the hot cracking in weld ${ }^{15}$. For dissimilar joining, the selection of proper filler is highly important. As reported the improper selection may cause liquation cracking in the weld zone and heat affected zone cracking ${ }^{16}$. The use of Ni-based filler was 
found to be helpful in reducing the thermal stresses and it does not promote the migration of $\mathrm{C}$ in the weld metal ${ }^{17}$. Yazdian et al. investigated on Hybrid laser/arc welding of 304L stainless steel tubes using different filler (A308LSi and A316LSi). They observed that the filler 316LSi show superior pitting resistance with lowest unstable passive region ${ }^{18}$. Jagesvar at al. studied the comparative effect of electrode (E2209 and E309L) on microstructural and mechanical properties of dissimilar weld. It was found that solidification of austenitic filler forms primary ferrite with austenitic matrix ${ }^{9}$. Vashishtha et al. investigated on effect of austenitic filler on microstructural and mechanical properties of low nickel austenitic stain less steel. They observed that E308 filler contain higher $\delta$ ferrite and results in increase tensile strength of the material than sample welded with E309 and E310 filler ${ }^{19}$. Schaeffler's and WRC-1992 are the predictive diagrams for the evaluation of the microstructure and $\delta$ ferrite of the weld zone ${ }^{20}$. This helps in attaining the desired microstructure by appropriate selection of welding electrodes to achieve desired properties in the weld. The predictive diagrams are based on the chemical compositions of the alloy and hence the solidification mode of the weld metal are not considered due to rapid solidification of the weld metal, it is difficult to predict the morphology of the weld. The pseudo-binary diagram helps in determining the solidification mode in the weld zone. $\mathrm{The}_{\mathrm{Cr}} / \mathrm{Ni}_{\mathrm{eq}}$ ratio helps in predicting the microstructure based on the cooling rate.

The corrosion behavior of the weld metal was mainly depending upon the chemical composition, microstructure and the formation of phase like sigma, chi and chromium carbide precipitation which forms due to the decomposition of $\delta$-ferrite at higher temperature ${ }^{21}$. The increase in $\delta$-ferrite content in the weld zone was beneficial in a solution containing $3.5 \% \mathrm{NaCl}$ as reported by Subodh et al. ${ }^{22}$. Shaogang et. al. observed finer grains in the weld metal produced by the GTAW process and finer grains help in resisting pitting corrosion ${ }^{23}$. Thus obtaining appropriate the microstructure in the weld with desired mechanical and corrosion properties is highly essential. However, systematic investigation on the selection of fillers for economical welding of low Ni SS (Cr$\mathrm{Mn} \mathrm{SS}$ ) and $304 \mathrm{SS}$ dissimilar joint is required. Therefore, the author had attempted to investigate welding of these dissimilar metals, with three different types of fillers and to understand their role on metallurgical, mechanical and electrochemical behavior of materials.

\section{Materials and Method}

The base metals (BMs) selected for the study were low $\mathrm{Ni}$ or Cr-Mn SS and 304 SS plates. The filler materials 308L, $316 \mathrm{~L}$ and $310 \mathrm{SS}$ with $2.15 \mathrm{~mm}$ diameter was used for joining plates. The chemical composition of the steels and fillers are given in Table 1. The welding was performed in the plane position with the dimensions of $150 \mathrm{~mm} \times 75 \mathrm{~mm} \times 3 \mathrm{~mm}$ plate of both the steels. The tungsten inert gas welding (TIG) process was selected (argon gas with the flow rate of $15 \mathrm{~L} /$ min) for joining the plates having welding parameters as shown in Table 2. The heat input was calculated according to the given Eq 1 .

Heat input (HI) in $k J / m m=V \times I / 1000 \times S$

Where, V is the voltage (V), I is the current (A) and S is the welding speed $(\mathrm{mm} / \mathrm{s})$. The photographs of welded samples are shown in Figure 1. Samples for various tests were cut using an electric discharge machine (EDM). Metallographic specimens were abraded on a series of emery papers $(220,320,400,600,800,1000,1200$ grit) followed by mirror polishing using diamond paste. The samples were etched by Marble's reagent $\left(50 \mathrm{ml} \mathrm{HCl}, 10 \mathrm{gm} \mathrm{CuSO}_{4}, 50\right.$ $\mathrm{ml}$ double distilled water) for welded zone and by $10 \mathrm{wt} \%$ oxalic acid for base metals and heat affected zone (HAZ) ${ }^{5}$. For metallography analysis, an optical microscope (OM), scanning electron microscope (SEM-JOEL 6380A) attached with energy dispersive spectroscopy (EDS) were used. A Fisher Ferritoscope (model FMP30) was used to determine ferrite number. Microhardness of welded samples was measured on the transverse section of weld samples using Vickers microhardness (Shimadzu micro-hardness tester). The load of $0.5 \mathrm{kgf}$ with the dwell time of 10 seconds was used in microhardness measurements. The tensile test was carried out using universal testing machine (INSTRON-model 4467) as per ASTM E8 M-04. Impact tests were carried out as per ASTM standard E23.

Electrochemical test was performed in $3.5 \% \mathrm{NaCl}$ solution using three electrode electrochemical cell using potentiostat (BioLogic VMP-300). Saturated calomel electrode (SCE) was used as the reference electrode and platinum gauze was used as the counter electrode and sample as the working electrode. The cell was allowed to reach stable open circuit potential before conducting electrochemical impedance spectroscopy (EIS) and potentiodynamic polarization tests (PDP). EIS test was carried out in the frequency range of $0.01 \mathrm{~Hz}$ to $10^{6} \mathrm{~Hz}$ using a sinusoidal AC signal of $10 \mathrm{mV}$. The results of EIS are presented in the form of Nyquist and Bode plots and Randle's equivalent circuit was used for fitting the Nyquist curves. The PDP was carried out at a scan rate of $0.1667 \mathrm{mV} / \mathrm{s}$ in potentiostat. Corrosion current densities $\left(i_{\text {corr }}\right)$ of the samples were determined from Tafel extrapolation by extending the linear portions of anodic and cathodic branches to a horizontal line drawn on $\mathrm{E}_{\text {corr }}$. Linear portions of anodic and cathodic branches were used for the measurement of anodic and cathodic slopes (Figure 8-a) ${ }^{24}$. Galvanic current density was measured for three hours using a zero resistance ammeter (ZRA) attached with a potentiostat. 
Table 1. Chemical composition of steels and fillers in wt (\%)

\begin{tabular}{ccccccccccc}
\hline Elements & $\mathbf{C r}$ & $\mathbf{M n}$ & $\mathbf{S i}$ & $\mathbf{N i}$ & $\mathbf{P}$ & $\mathbf{S}$ & $\mathbf{C}$ & $\mathbf{N}$ & $\mathbf{M o}$ & $\mathbf{F e}$ \\
\hline Cr-Mn SS & 16.46 & 9.14 & 0.46 & 0.19 & 0.014 & 0.0104 & 0.13 & 0.06 & - & Balance \\
304 SS & 18.90 & 1.65 & 0.50 & 9.32 & 0.005 & 0.006 & 0.067 & - & - & Balance \\
308L & 20.31 & 0.80 & 0.52 & 9.65 & 0.01 & 0.02 & 0.08 & - & - & Balance \\
316L & 18.90 & 0.80 & 0.50 & 12 & 0.01 & 0.02 & 0.04 & - & 2.5 & Balance \\
310 & 26.0 & 1.5 & 0.49 & 21.5 & 0.01 & 0.01 & 0.10 & - & - & Balance \\
\hline
\end{tabular}

Table 2. Welding process parameters

\begin{tabular}{ccccc}
\hline $\begin{array}{c}\text { Welding current } \\
(\mathbf{I})\end{array}$ & $\begin{array}{c}\text { Welding voltage } \\
(\mathbf{V})\end{array}$ & $\begin{array}{c}\text { Speed } \\
(\mathbf{m m} / \mathbf{s})\end{array}$ & $\begin{array}{c}\text { Heat input } \\
(\mathbf{k J} / \mathbf{m m})\end{array}$ & $\begin{array}{c}\text { Electrode Diameter } \\
(\mathbf{m m})\end{array}$ \\
\hline 120 & 20 & 3.7 & 0.64 & 2.14 \\
120 & 21 & 3.72 & 0.67 & 2.14 \\
120 & 20 & 3.71 & 0.64 & 2.14 \\
\hline
\end{tabular}

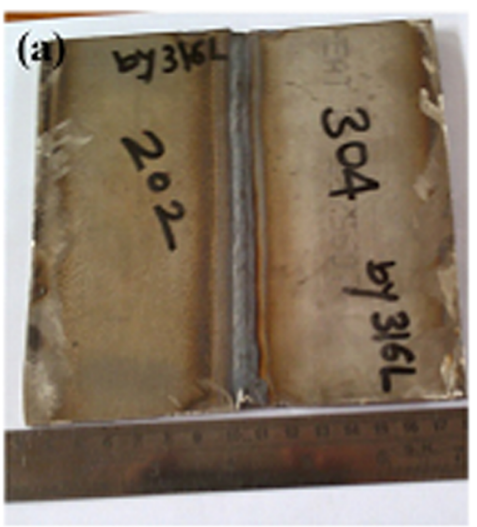

(a) $316 \mathrm{~L} \mathrm{SS}$

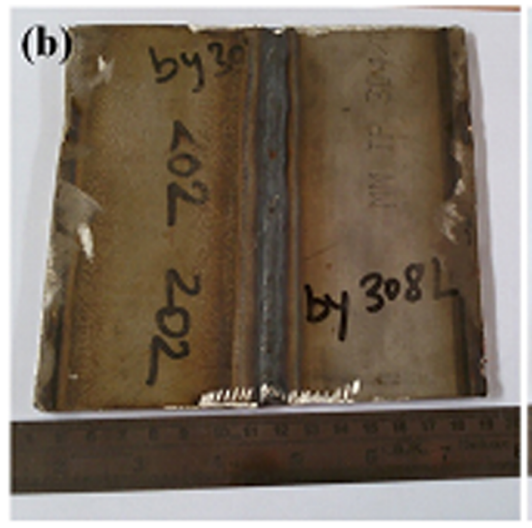

(b) $308 \mathrm{~L} \mathrm{SS}$

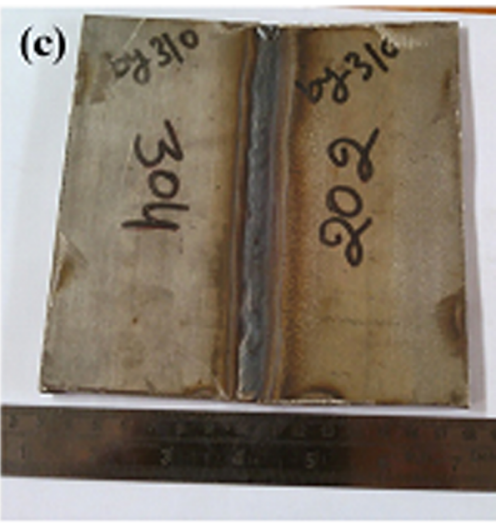

(c) $310 \mathrm{SS}$

Figure 1. Photograph of dissimilar welded samples welded by (a) 316 L SS (b) 308 L SS and (c) 310 SS

\section{Results and Discussions}

\subsection{Microstructural characterization}

Figure 2 (a) and (b) shows the optical microstructure of base metals. The microstructure consists of fully austenitic structures having equiaxed grains with twins and no other precipitate was observed in the microstructure. The grain size was measured for both the steels and was found to be in the range between $100 \mu \mathrm{m}$ to $150 \mu \mathrm{m}$. Figure 3 (a-c) shows the optical microstructure of dissimilar welded samples. The Figure 3 (a) shows the microstructure of the sample welded by $316 \mathrm{~L}$ SS filler; it mainly comprises of austenite $(\gamma)$ and dendritic structure ( $\delta$-ferrite). The $\delta$-ferrite is present in the form of lacy ferrite and vermicular ferrite. More lacy ferrite was observed in the microstructure, which follows Kurdjumov-Sachs (K-S) relationship with austenite ${ }^{25}$, due to low energy $\delta / \gamma$ boundary and causes higher coherency between the boundaries. Whereas in the case of vermicular ferrite no such relationship exists ${ }^{25,26}$. The orientation of lacy ferrite is different from the orientation of vermicular ferrite which was characterized by the $\delta$-ferrite moving across to the opposite grain boundary as shown in Figure 3 (a). Figure 3 (b) shows the dissimilar joint welded by 308L SS electrode. The weld microstructure consists of vermicular and lacy ferrite similar to Figure 3(a). However, it was observed that the structure was mainly dominated by vermicular ferrite which may be due to lower $\mathrm{Cr}_{\text {eq }} / \mathrm{Ni}_{\text {eq }}$ ratio of $308 \mathrm{~L}$ filler ${ }^{26}$. Figure 3 (c) shows the microstructure of the $310 \mathrm{SS}$ welded sample. The microstructure consists of columnar dendritic structure. The formation of this structure is mainly due to the presence of alloying element ( $\mathrm{Fe}, \mathrm{Cr}$ and $\mathrm{Ni}$ ). Because, $\mathrm{Fe}, \mathrm{Cr}$ and $\mathrm{Ni}$ have low tendency to segregate in the intergranular and interdendritic regions and this produces completely columnar structure. Figure 4 (a-c) shows the SEM micrograph of all the weld zones of different fillers.

The unmixed zone (interfacial microstructure) was observed in all the three welded specimens on both the sides (304 SS and Cr-Mn SS) due to the melting and solidification of base metals with the weld metal. Wider unmixed zone (UMZ) was observed at the interface of weld in Cr-Mn SS 


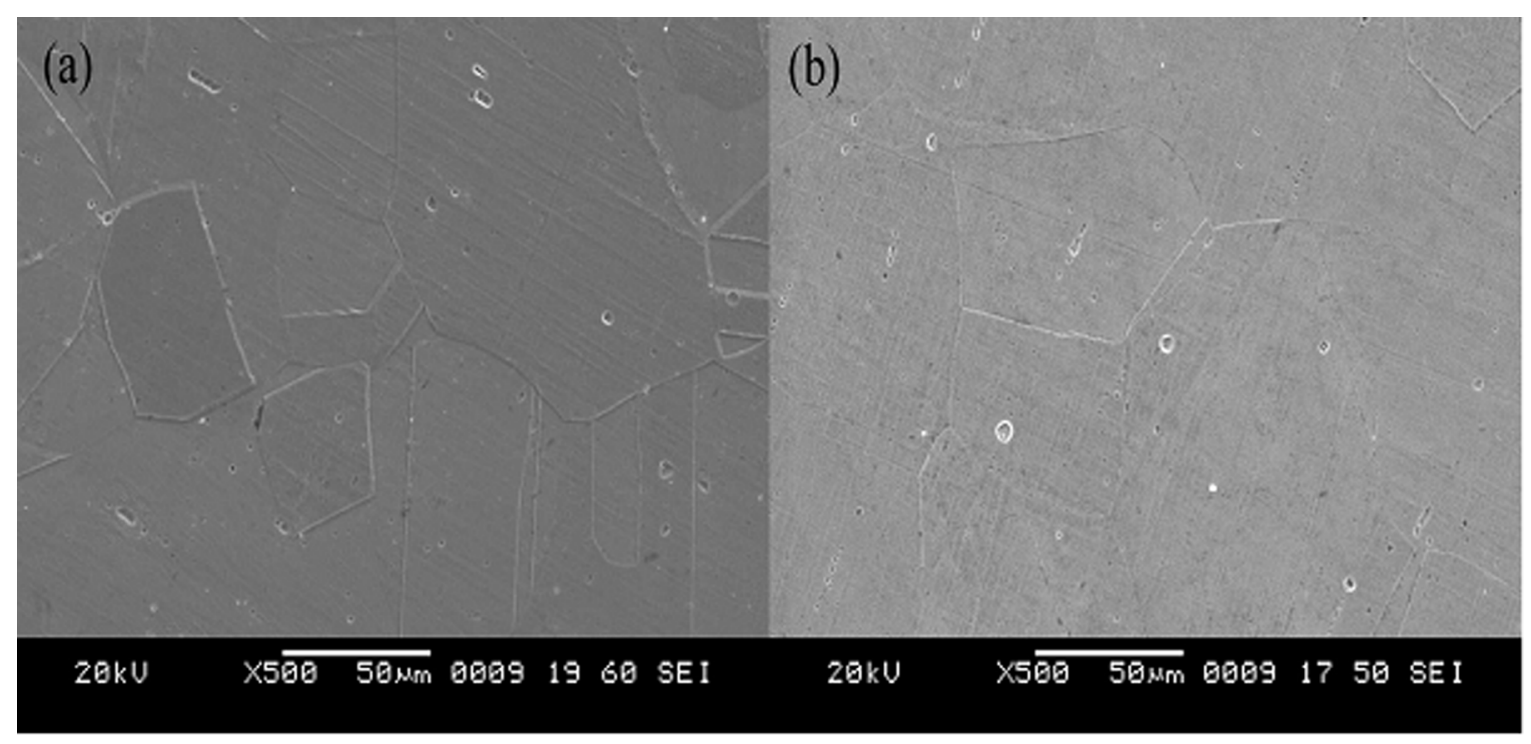

(a) Cr-Mn SS

(b) $304 \mathrm{SS}$

Figure 2. Optical microstructures of base metal (a) Cr-Mn SS and (b) 304 SS

for all the weld samples and data is listed in Table 3. The heat affected zone (HAZ) was observed in all the cases and the measured width is listed in Table 3. However, more width of HAZ was observed in Cr-Mn SS side as compared to 304 $\mathrm{SS}$, which may be due to the higher thermal conductivity of Cr-Mn SS ${ }^{5}$. The ferrite content was measured using Ferritoscope and presented in Table 3. More $\delta$-ferrite was observed in $316 \mathrm{~L} \mathrm{SS}$ as compared to other welds (308 L SS and $310 \mathrm{SS}$ ). Whereas no ferrite content was observed in the $310 \mathrm{SS}$ weld samples since it solidified in fully austenitic mode. The dilution of all the weld samples was calculated using the geometrical method with the help of given equation (Eq. 4) and listed in Table 3.

$$
\begin{gathered}
A_{W D}=A_{R G}+A_{T R}+A_{B F}+A_{R R} \\
A_{B F}=A_{W D}-A_{R G}-A_{T R}-A_{R R} \\
\text { Dilution } \%=A_{B F} / A_{W D} \times 100
\end{gathered}
$$

Where $A_{W D}$ is the area of the weld deposit, $A_{T R}$ is the top area, $A_{R R}$ is the root area, $A_{B F}$ is the reinforcement area of base metal fusion, and $A_{R G}$ is the root gap area. To predict the welding microstructure and the amount of ferrite content in the weld, Schaeffler's diagram are extensively used. However, welding of the SS may contain the small amount of ferrite in weld zone which may be difficult to see from the microstructure. Hence, the correlation between the predicted weld structure and the structure after welding is necessary. Figure 4 (d) shows the Schaeffler diagram and location of the fillers. It is observed that 310 filler lies in the region of fully austenitic structure. Hence, there is no ferrite content in the weld matrix. Whereas the steels welded from 308L and 316L SS filler show the ferrite content $7.10 \%$ and $9.62 \%$ respectively and the weld structure consists of austenite and retained ferrite ( $\delta$-ferrite) in the weld matrix. According to the Schaeffler diagram, the $\mathrm{Cr}_{\text {eq }}$ and $\mathrm{Ni}_{\text {eq }}$ were calculated using the equations given below ${ }^{27}$.

$$
\begin{aligned}
C r_{e q}= & \% C r+\% M o+0.5 \% N b+ \\
& 1.5 \% S i+2 \% T i \\
N i_{e q}= & \% N i+30 \% C+0.5 \% M n
\end{aligned}
$$

Considering the chemical composition of the fillers as given in Table 1. The $\mathrm{Cr}_{\text {eq }}$ and $\mathrm{Ni}_{\text {eq }}$ were calculated and their respective locations are shown in Figure 4 (d). The solidification mode of all the weld electrode was evaluated by $\mathrm{Cr}_{\text {eq }}$ and $\mathrm{Ni}_{\text {eq }}$ ratio and plotted on the pseudo binary diagram as shown in Figure 4 (e). According to literature, there is four solidification mode as shown below ${ }^{28}$.

Austenite $\bmod e(A)$ :

$L \rightarrow(L+\gamma) \rightarrow \gamma,\left(C r_{e q} / N i_{e q}\right)<1.25$

Austenite - Ferrute $\bmod e(A F)$ :

$L \rightarrow(L+\gamma) \rightarrow(L+\gamma+\delta) \rightarrow$ 
Ferrite-Austenite mode( $F A)$ :

$L \rightarrow(L+\delta) \rightarrow(L+\delta+\gamma) \rightarrow$

$(\gamma+\delta), 1.48<\left(C r_{e q} / N i_{e q}\right)<1.95$

Ferrite $\bmod e(F): L \rightarrow(L+\delta) \rightarrow \delta \rightarrow(\gamma+\delta)$,

$\left(C r_{e q} / N i_{e q}\right)>1.95$
The solidification mode of $310 \mathrm{SS}$ was found to be 1.04 and for $308 \mathrm{~L} \mathrm{SS}$ was found to be 1.6 and for $316 \mathrm{~L} \mathrm{SS}$ weld electrode was 1.85. Hence, according to the Eqs. 7 - 10, the mode of solidification of $310 \mathrm{SS}$ weld is fully austenite (A mode) whereas that for the $308 \mathrm{SS}$ and $316 \mathrm{SS}$ welds is ferrite-austenite mode (FA mode). Figure 5 (a-c) shows energy dispersive spectroscopy scan (line scan) on macro-section of welding. Higher $\mathrm{Cr}$ content in the 304 SS side was observed

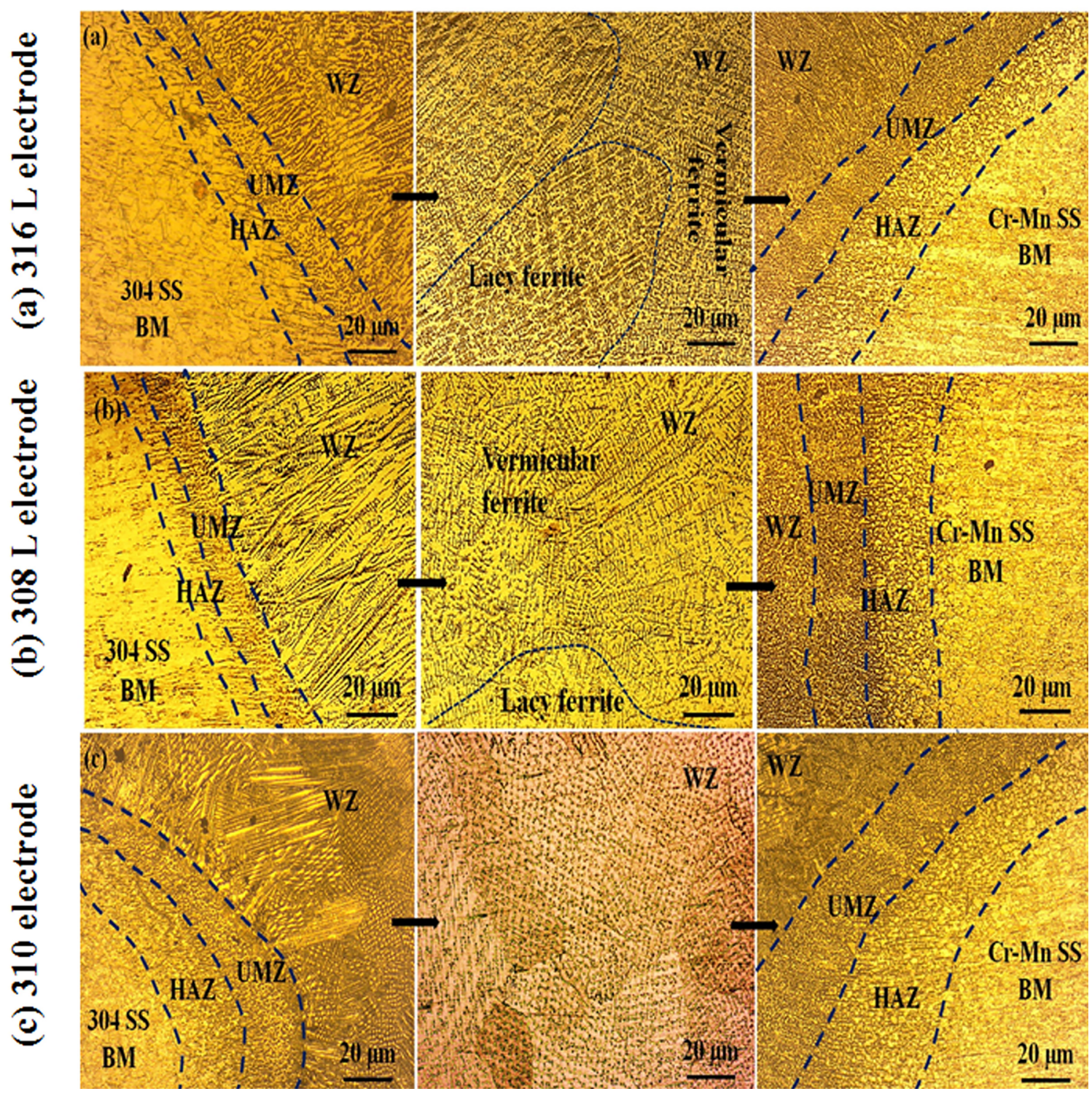

Figure 3. Optical micrographs of weld samples (a) $316 \mathrm{~L}$ electrode (b) $308 \mathrm{~L}$ electrode and (c) 310 electrode

Table 3. Microstructural details of welding

\begin{tabular}{|c|c|c|c|c|c|c|c|c|}
\hline \multirow[b]{2}{*}{$\begin{array}{l}\text { Welding } \\
\text { Electrodes }\end{array}$} & \multirow{2}{*}{$\begin{array}{c}\text { Unmixed } \\
\text { zone length } \\
(\mu \mathrm{m}) 304 \mathrm{SS}\end{array}$} & \multirow[b]{2}{*}{$\begin{array}{c}\text { HAZ } \\
\text { width }(\mu \mathrm{m})\end{array}$} & \multirow{2}{*}{$\begin{array}{c}\text { Unmixed } \\
\text { zone length } \\
(\mu \mathrm{m}) \mathrm{Cr}-\mathrm{Mn} \\
\text { SS }\end{array}$} & \multirow[b]{2}{*}{$\begin{array}{c}\text { HAZ } \\
\text { width }(\mu \mathrm{m})\end{array}$} & \multirow{2}{*}{$\begin{array}{c}\text { Average } \\
\text { level of } \\
\text { dilution } \\
(\%)\end{array}$} & \multicolumn{3}{|c|}{$\delta$ - ferriteby Ferritoscope(FN) } \\
\hline & & & & & & $\begin{array}{l}\text { Weld } \\
\text { zone }\end{array}$ & $\begin{array}{c}\text { Base metal } \\
\text { (304 SS) }\end{array}$ & $\begin{array}{l}\text { Base metal } \\
\text { (Cr-Mn SS) }\end{array}$ \\
\hline $316 \mathrm{~L} \mathrm{SS}$ & 180 & 245 & 257 & 498 & $24 \pm 3$ & 6.0 & 0.15 & 0.16 \\
\hline 308L SS & 181 & 240 & 250 & 452 & $25 \pm 3$ & 5.1 & 0.15 & 0.16 \\
\hline $310 \mathrm{SS}$ & 185 & 256 & 255 & 468 & $24 \pm 3$ & 0.14 & 0.15 & 0.16 \\
\hline
\end{tabular}



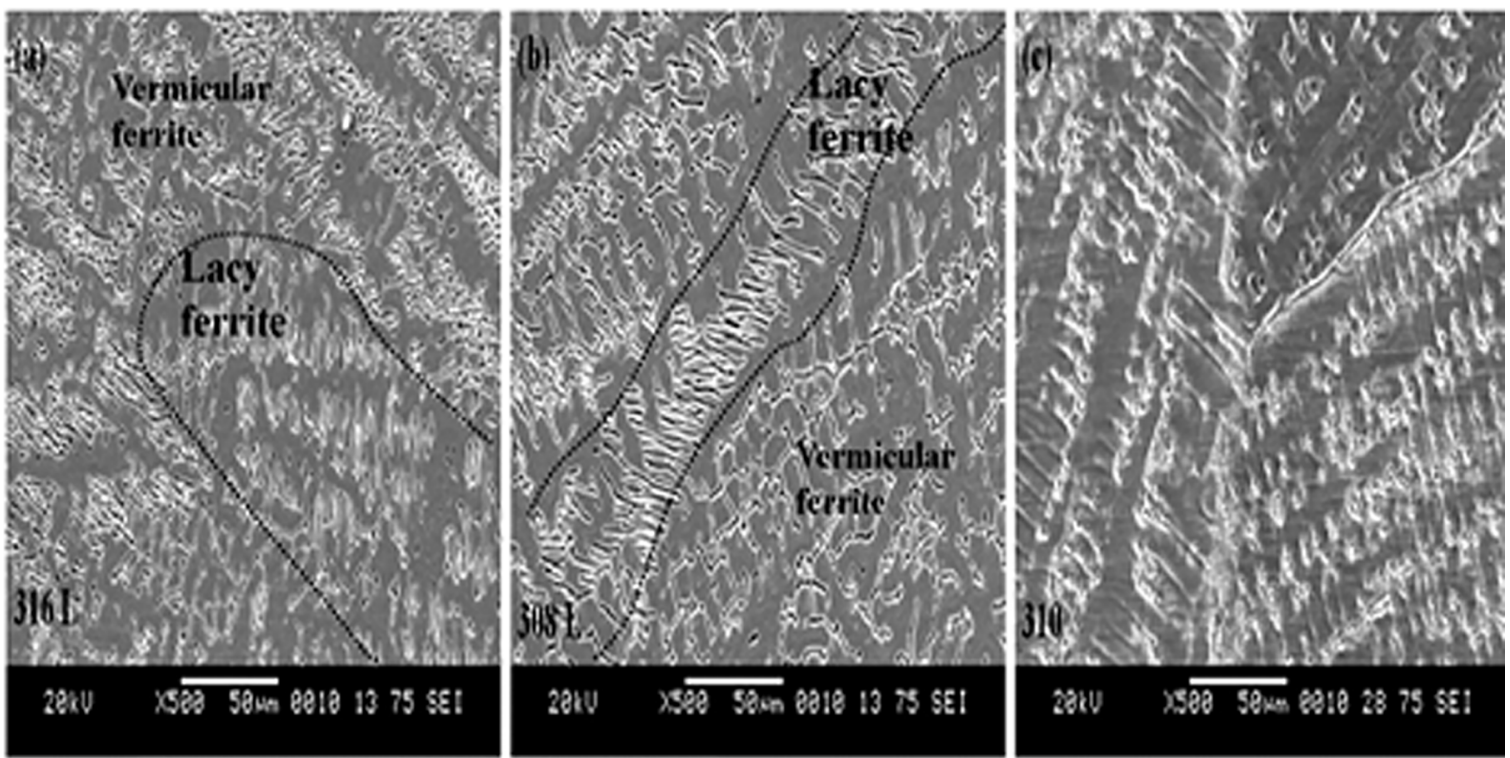

(d)

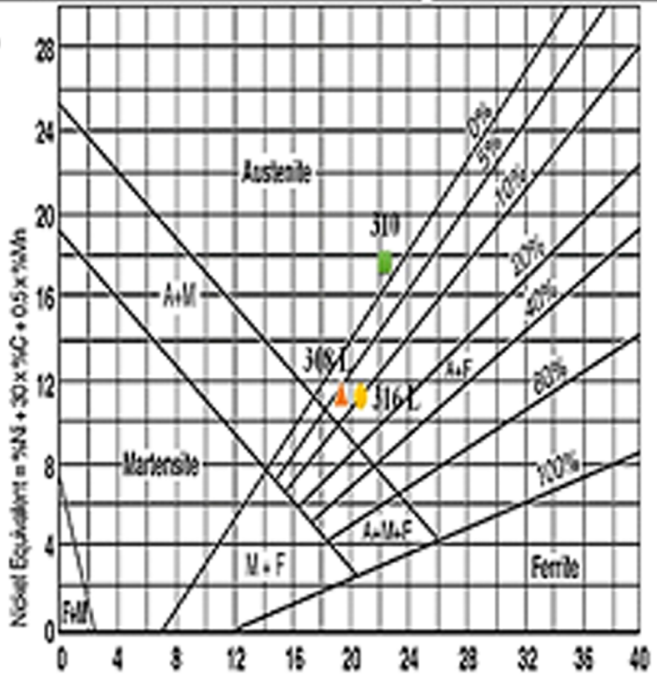

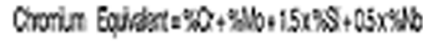

(d) Schaeffler diagram

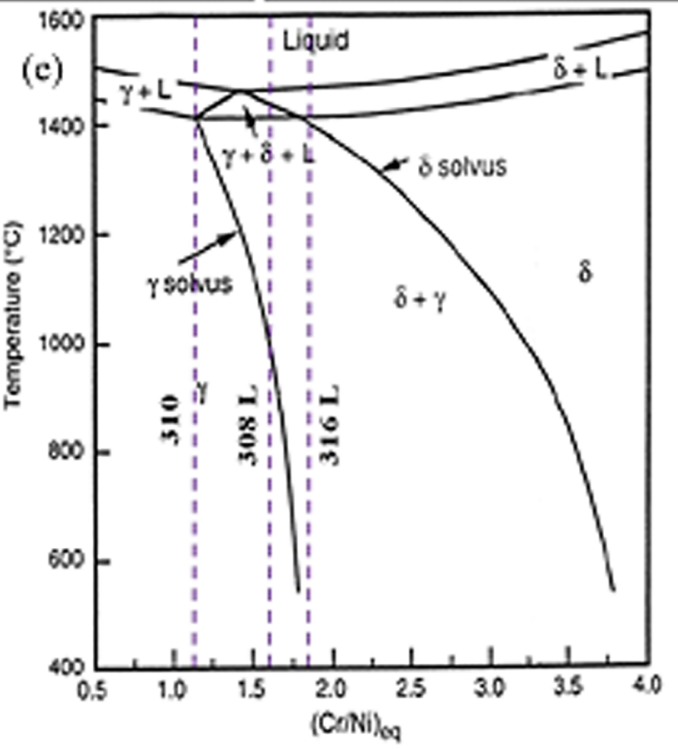

(e) Pseudo binary diagram showing the loci of each weld material

Figure 4. SEM micrograph of weld zones (a) ER316 L (b) ER308 L and (c) ER310 (d) Schaeffler diagram (e) Pseudo binary diagram showing the loci of each weld material

as compared to $\mathrm{Cr}-\mathrm{Mn} \mathrm{SS}$. Whereas, variation in $\mathrm{Mn}$ and $\mathrm{Ni}$ can be seen clearly observed as shown in Figure 5. Table 4 shows the chemical composition of $\delta$ ferrite and austenite which was evaluated using point scan (average of 5 scans). It was observed that $\delta$ ferrite contain higher amount of $\mathrm{Cr}$ contents than in austenite ( $\gamma$ phase) in $316 \mathrm{~L}$ and $308 \mathrm{~L}$ $\mathrm{SS}$, whereas, in $310 \mathrm{SS}$ there is no such distinct chemical composition variation in 310 SS welds.

\subsection{Mechanical testing}

Figure 6 shows the microhardness profile across the weld specimens. It was noticed that the measured value of hardness for Cr-Mn SS and $304 \mathrm{SS}$ is $250 \mathrm{HV}$ and $230 \mathrm{HV}$ respectively among all the welds. Highest hardness was found in sample welded with $316 \mathrm{~L} \mathrm{SS}(226 \mathrm{HV})$, this is due to the formation of more $\delta$-ferrite in the weld metal. The weld of 308L SS and $310 \mathrm{SS}$, have a hardness of $218 \mathrm{HV}$ and $210 \mathrm{HV}$ respectively.

Figure 7 (a) shows the tensile specimen of welded joints after fracture. It was observed that base metal Cr-Mn SS has higher tensile strength than $304 \mathrm{SS}$. The tensile strength of welded samples is listed in Table 5. All the welded samples were fractured at $304 \mathrm{SS}$ (base metal side) which indicated that the weld possessed sufficient strength and is stronger 


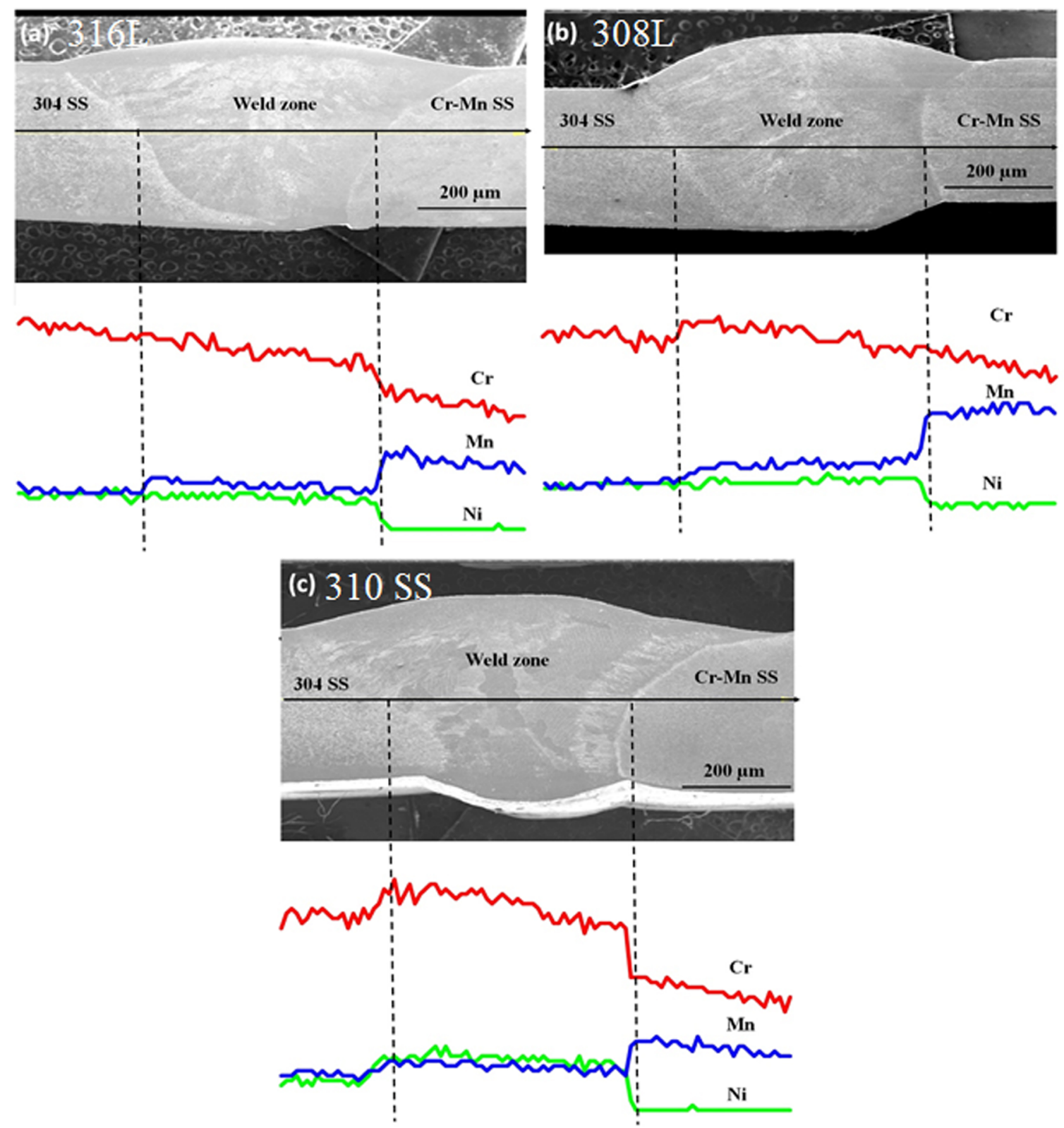

Figure 5. EDS (line scan) analysis of different weld samples (a) 316L (b) $308 \mathrm{~L}$ and (c) $310 \mathrm{SS}$ filler

Table 4. Chemical composition (wt \%) of different phases

\begin{tabular}{lcccc}
\hline \multirow{2}{*}{ Steels } & \multirow{2}{*}{ Phase } & \multicolumn{3}{c}{ Chemical composition (wt \%) } \\
\cline { 3 - 5 } & & $\mathbf{C r}$ & $\mathbf{N i}$ & $\mathbf{M n}$ \\
\hline \multirow{2}{*}{ 316L SS } & $\delta$-ferrite & 22.21 & 8.98 & 0.40 \\
& $\gamma$-austenite & 18.85 & 11.75 & 1.55 \\
\multirow{2}{*}{ 308L SS } & $\delta$-ferrite & 21.20 & 5.61 & 0.70 \\
& $\gamma$-austenite & 18.77 & 9.21 & 1.72 \\
\hline \multirow{2}{*}{ 310 SS } & $\gamma$-austenite & 26.03 & 20.40 & 1.45 \\
\hline
\end{tabular}

than the base metal. In all the weld joints the factors like solid solution strengthening, higher $\mathrm{Cr}_{\mathrm{eq}} / \mathrm{Ni}_{\mathrm{eq}}$ ratio and weld morphology increase the restraint of the weld and weld restraint may cause some variation in tensile strength as observed in Table $5^{29}$. Figure 7 (b)shows the Charpy V-notch impact specimen of different weld samples. The fractography analysis of welded samples is shown in Figure 7 (b). The specimens welded from 316L, 308L SS and 310 SS show fine dimple in its microstructure. The failure mode of all the welded samples, therefore, appears to be ductile in natures. Impact value was found to be $59 \mathrm{~J}, 55 \mathrm{~J}$ and $52 \mathrm{~J}$ for 310 , 308L and 316L SS respectively. This shows that the weld of 310 requires more energy for fracture. 


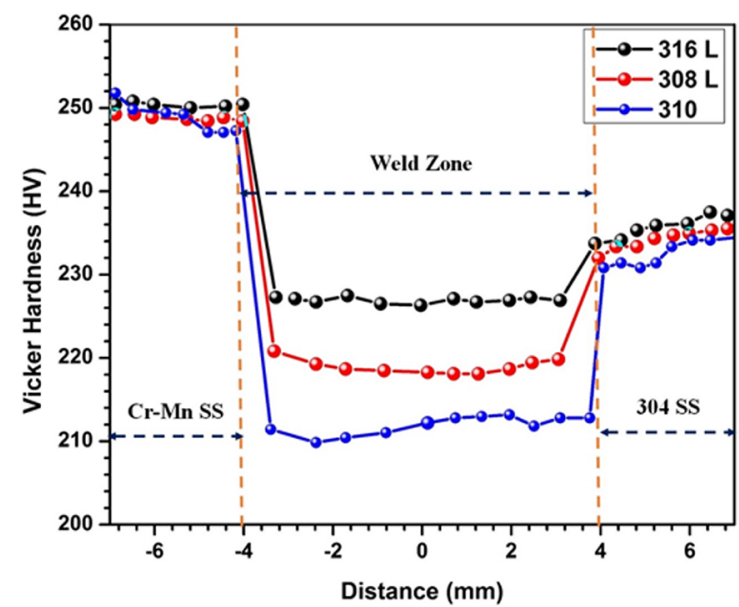

Figure 6. Microhardness profile across the weld specimens

\subsection{Electrochemical behavior}

\subsubsection{Potentiodynamic polarization curves}

Figure 8 (a) shows the graphical representation of Tafel extrapolation to estimate of $\mathrm{E}_{\text {corr }}$ and $i_{\text {corr }}$ from potentiodynamic polarization plots (PDP). Figure 8 (b) shows PDP plots of base metals and weld zones of different welds in aerated $\mathrm{NaCl}$ solution $(3.5 \% \mathrm{NaCl})$ at $30{ }^{\circ} \mathrm{C}$. The corrosion current density $\left(i_{\text {corr }}\right)$ and corrosion potential $\left(\mathrm{E}_{\text {corr }}\right)$ were obtained from these plots by Tafel extrapolation and is shown in Table 6. Tafel extrapolation also yields anodic and cathodic Tafel slopes. Anodic part of the base metal shows that anodic current density increases and then decreases and further increases very slowly on polarization from $-0.5 \mathrm{~V}$ (SCE) to $-0.1 \mathrm{~V}(\mathrm{SCE})$ and then decreases slightly before reaching
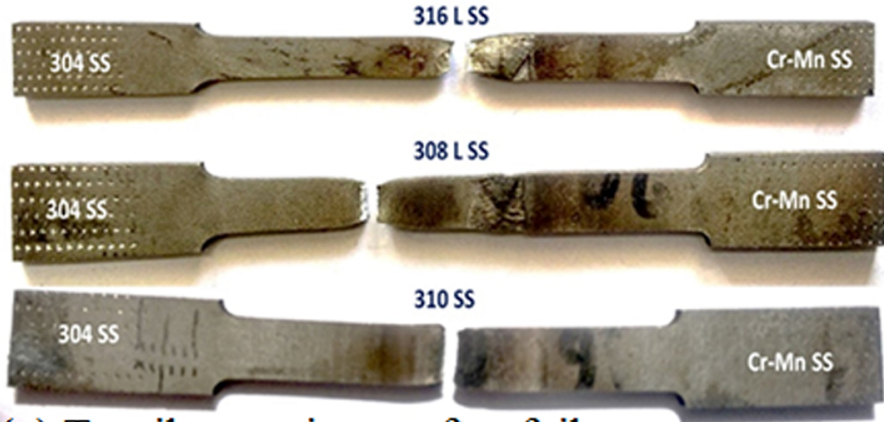

(a) Tensile specimen after failure

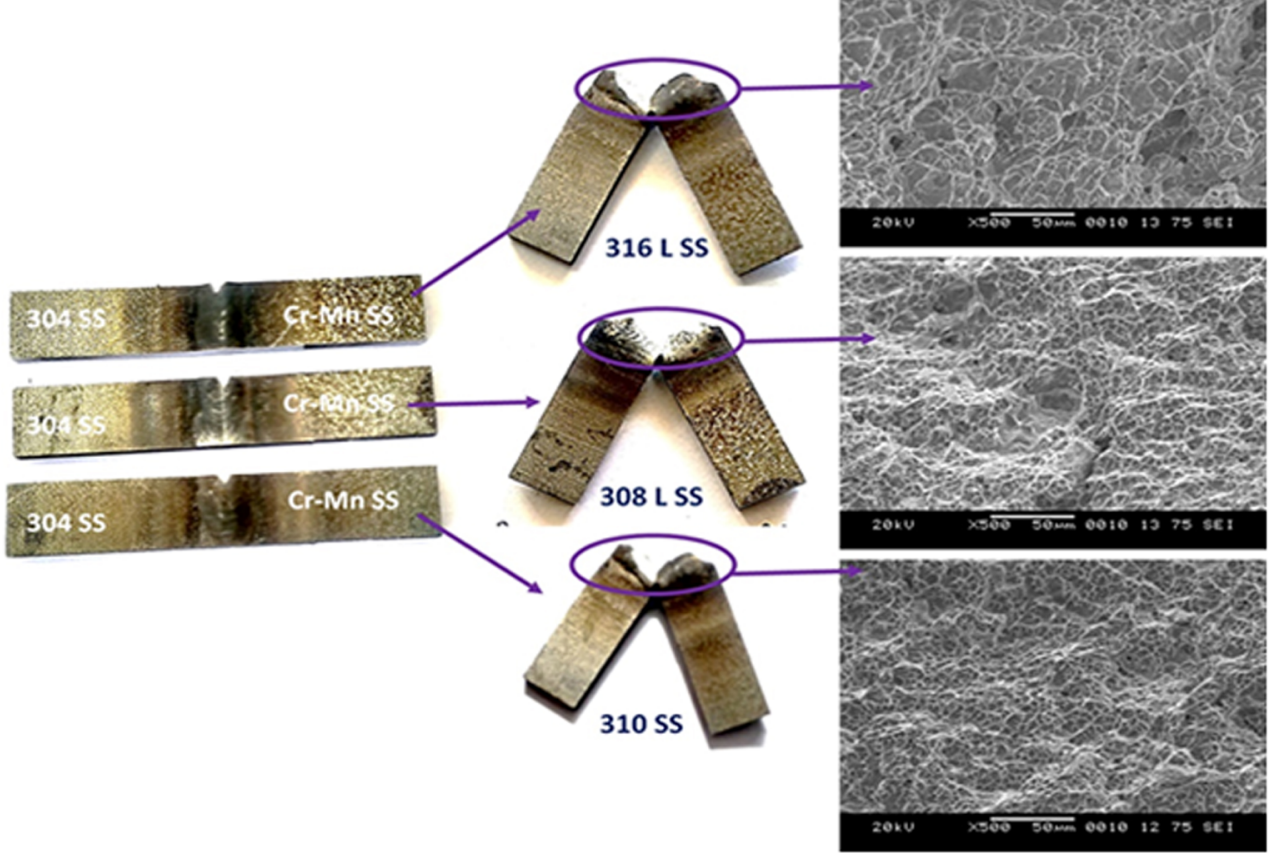

(b) Impact test of various weld joints and its respective SEM micrograph

Figure 7. (a) Tensile specimen after failure (b) Impact test of various weld joints and its respective SEM micrograph 
pitting potential $\left(\mathrm{E}_{\mathrm{pit}}\right)(0.13 \mathrm{~V}$ (SCE) for Cr-Mn SS and 0.21 $\mathrm{V}$ (SCE) for $304 \mathrm{SS})$. The current density of anodic plots of weld increases slowly (at a rate faster than the current density of base metal) until $\mathrm{E}_{\text {pit }}$. In general, the chemical composition plays an important role in the stability of the metal. The electrochemical reactions occur at the metal surface in presence of chloride ions are anodic reactions (dissolution of $\mathrm{Fe}, \mathrm{Cr}$ and $\mathrm{Ni}$ ) and cathodic reactions (oxygen reduction). It was observed that there is a shift in corrosion potential $\mathrm{E}_{\text {corr }}$ in $\mathrm{Cl}^{-}$environment to more positive values from base metal to different weld metal. This shift is due to the more stable self-protective layer $\left(\mathrm{Cr}_{2} \mathrm{O}_{3}\right)$ formed over the surface of the samples ${ }^{30}$. The $\mathrm{E}_{\text {corr }}$ shifts towards the positive potential from Cr-Mn SS and 304 SS followed by welded samples $(310,308 \mathrm{~L}$ and $316 \mathrm{~L} \mathrm{SS})$ respectively. It was reported that with the increase in $\mathrm{NaCl}$ concentration, shift the pitting potential $\left(\mathrm{E}_{\text {pit }}\right)$ toward the active direction, which indicated the decrease in pitting corrosion resistance in the metal. A linear relationship coexists between the $\mathrm{Cl}^{-}$ concentrations according to the Eq. $11^{30}$.

$$
E_{p i t}=a-b \log C_{C l-}
$$

Where $\mathrm{a}$ and $\mathrm{b}$ are constants and depends upon the chemical composition of the alloy. Hence, at a given $\mathrm{Cl}^{-}$ concentration the value of $\mathrm{E}_{\text {pit }}$ mainly depends upon the chemical composition of the alloy. Figure 8 (b) represents all the samples showing pitting susceptibility against chloride ions. The potential at which there is a sharp increase in the curve or there is a sudden increase in anodic current density

Table 5. Tensile test results

\begin{tabular}{lccccc}
\hline & \multicolumn{2}{c}{ Base metals } & \multicolumn{2}{c}{ Dissimilar joint welded by different fillers } \\
\cline { 2 - 6 } & Cr-Mn SS & $\mathbf{3 0 4}$ SS & 316L & $\mathbf{3 1 0}$ & 308L \\
\hline Yield strength (MPa) & 222.6 & 335.2 & 336.7 & 330.4 & 333.3 \\
Ultimate tensile strength (MPa) & 808.7 & 670 & 667.50 & 660.0 & 667.9 \\
\% elongation & 60.2 & 52.5 & 50.34 & 49.5 & 55.2 \\
Fracture zone & --- & --- & 304 & 304 & 304 \\
\hline
\end{tabular}

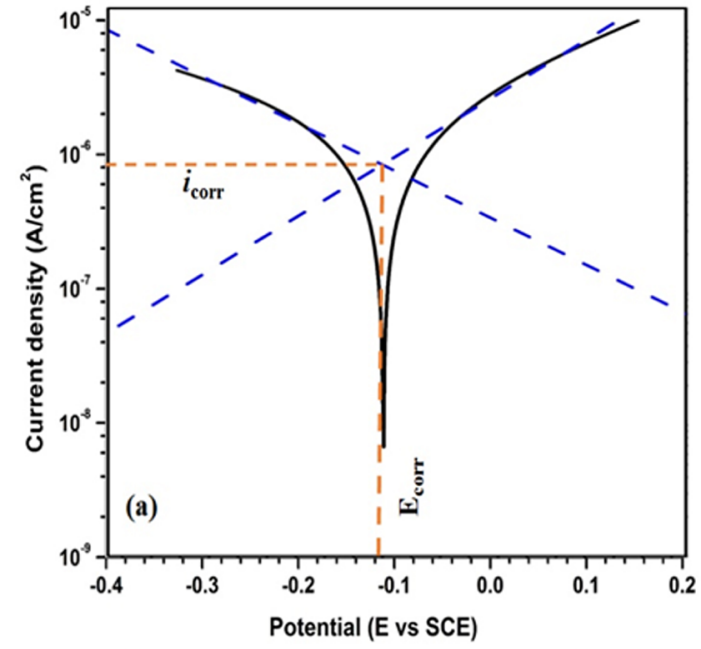

(a) Graphical representation of Tafel extrapolation for estimating of $\mathbf{E}_{\text {corr }}$ and $\boldsymbol{i}_{\text {corr }}$

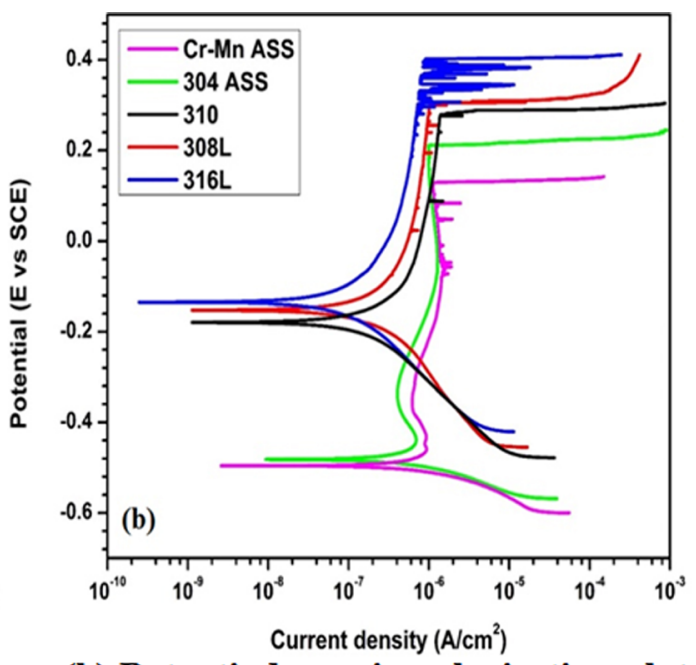

(b) Potentiodynamic polarization plots of various samples

Figure 8. (a) Graphical representation of Tafel extrapolation for estimating of $\mathrm{E}_{\text {corr }}$ and $i_{\text {corr }}$ (b) Potentiodynamic polarization plots of various sample

Table 6. Potentiodynamic polarization data for base metal and welded samples

\begin{tabular}{lccccc}
\hline Samples & $\mathbf{E}_{\text {corr }}(\mathbf{m V})$ & $i_{\text {corr }}\left(\boldsymbol{\mu} \mathbf{A} / \mathbf{m}^{2}\right)$ & $\boldsymbol{\beta a ~}(\mathbf{m V})$ & $\boldsymbol{\beta c}(\mathbf{m V})$ & $\mathbf{E}_{\text {pit }}(\mathbf{m V})$ \\
\hline Cr-Mn SS & -497.5 & 0.576 & 97.5 & 60.6 & 132.4 \\
304 SS & -479.7 & 0.390 & 105.6 & 65.4 & 212.5 \\
316L SS & -131.6 & 0.108 & 335.6 & 243.6 & 403.7 \\
308L SS & -149.1 & 0.240 & 274.0 & 179.4 & 303.0 \\
310 SS & -180.0 & 0.261 & 305.4 & 171.0 & 282.0 \\
\hline
\end{tabular}


is known as pitting potential $\left(\mathrm{E}_{\mathrm{pit}}\right)$. It was observed that $\mathrm{Cr}$ Mn SS showed lower $\mathrm{E}_{\text {pit }}$ as compared to 304 SS base metal. This may be due to lower $\mathrm{Cr}$ content in the base metal of $\mathrm{Cr}-\mathrm{Mn} \mathrm{SS}$. It had been reported that passive film form over the surface gets deteriorate due to $\mathrm{Cl}^{-}$. This may be due to the intermediate complex form over the film caused by adsorb chloride ions. This leads to the preferential site for pit initiation ${ }^{31}$. Once the pit is initiated or nucleated the pitting growth and propagation is continued in active dissolution mode. $\mathrm{c}$ inside the pit as shown in Eq. 12 and $13^{32}$.

$$
\begin{aligned}
& F e \rightarrow F e^{2+}+2 e \\
& C r \rightarrow C r^{3+}+3 e
\end{aligned}
$$

It was observed that below $\mathrm{E}_{\text {pit }}$ (passive potential) there are fluctuations in the current densities. This fluctuation in the current density may be due to the breakdown of the passive film in the form of metastable pit ${ }^{33}$. Hence, the formation of metastable pitting can be observed in all specimens. With further increase in potential results in the stable pit on the surface $\left(\mathrm{E}_{\text {pit }}\right)$. The weld metal of $310 \mathrm{SS}$ showed lower pitting potential as compared with the rest of the welded samples (308L and 316L). The highest $\mathrm{E}_{\text {pit }}$ was found to be in welded samples of $316 \mathrm{~L} \mathrm{SS}$. The value of $i_{\text {corr }}$ was larger for base metal than the welded samples. The lower $i_{\text {corr }}$ value was found to be in weld sample of $316 \mathrm{~L} \mathrm{SS}$ as compared to $308 \mathrm{~L}$ and $310 \mathrm{SS}$.

Figure 9 (a-c) shows the SEM micrograph of the welded samples after polarization. In Figure $9(a-b)$ it was observed that pit formed at the austenite phase of $316 \mathrm{~L}$ and $308 \mathrm{~L}$ weld sample. Whereas in Figure 9 (c) pit was formed all over the surface. It is known that alloying element play an important role in stabilizing the phases and therefore influence the corrosion behavior of weld metal. As shown in Table 4, EDS analysis reveals higher $\mathrm{Cr}$ content in $\delta$ ferrite as compared to $\gamma$ phase in $316 \mathrm{~L}$ and $308 \mathrm{~L}$ weld sample. Due to lower $\mathrm{Cr}$ content in the $\gamma$-austenite phase becomes the preferential site for the breakdown of passivity ${ }^{34}$. Also, it was reported that $\delta$ ferrite content in the weld helps in improving pitting resistance ${ }^{35}$. As higher $\delta$ ferrite content was observed in $316 \mathrm{~L} \mathrm{SS}$ also the beneficial effect of molybdenum (Mo) in weld sample, results in better pitting resistance against $\mathrm{Cl}^{-}$. It had been reported that smaller grains promote the formation of passive film and degree of protectiveness and stability of the passive film increase with the decrease in grain size ${ }^{36}$. Jiang et al. reported that with the increase in $\mathrm{Cr}$ content exhibit stable passive in anodic part of polarization plot exhibited stable passivity ${ }^{37}$. Hence the difference between polarization diagram of base metals (304 and Cr-Mn SS) and weld metal (316L, 308L and $310 \mathrm{SS}$ ) may be due to the difference in the grain size and $\mathrm{Cr}$ content of the steel and weld samples. The pitting potential of all the specimens may be summarized as.

$\mathrm{E}_{\text {pit }}($ Cr-Mn SS base metal $)<\mathrm{E}_{\text {pit }}(304 \mathrm{SS}$ base metal $)<$ $\mathrm{E}_{\text {pit }}(310$ weld $)<\mathrm{E}_{\text {pit }}(308 \mathrm{~L}$ weld $)<\mathrm{E}_{\text {pit }}(316 \mathrm{~L}$ weld $)$

\subsubsection{Electrochemical impedance spectroscopy}

Figure 10 ( $a$ and $b$ ) shows the electrochemical impedance spectroscopy (EIS) in the form of Nyquist and Bode plots. Randle equivalent circuit diagram where used for curve fitting, where $R_{s}$ is the solution resistance, $R_{p}$ is the polarization resistance or resistance offered by the passive film and CPE is the double layer capacitance. The fitted data is shown in Table 7. The Nyquist plot shows the semicircle having the capacitive loop at lower frequency range. The capacitance is the intact passive film of $\mathrm{Cr}_{2} \mathrm{O}_{3}{ }^{38}$. The capacitance is inversely proportional to film thickness $\mathrm{L}$, thus smaller the capacitance value larger would be the film thickness as given in Eq. 14.

$$
L=\varepsilon \varepsilon_{o} A / C
$$

Where $\mathrm{C}$ is the total capacitance of the passive film, $\varepsilon$ is the dielectric constant of the oxide film, $\varepsilon_{0}$ is the permittivity of space and $\mathrm{A}$ is the electrode area. It was observed from
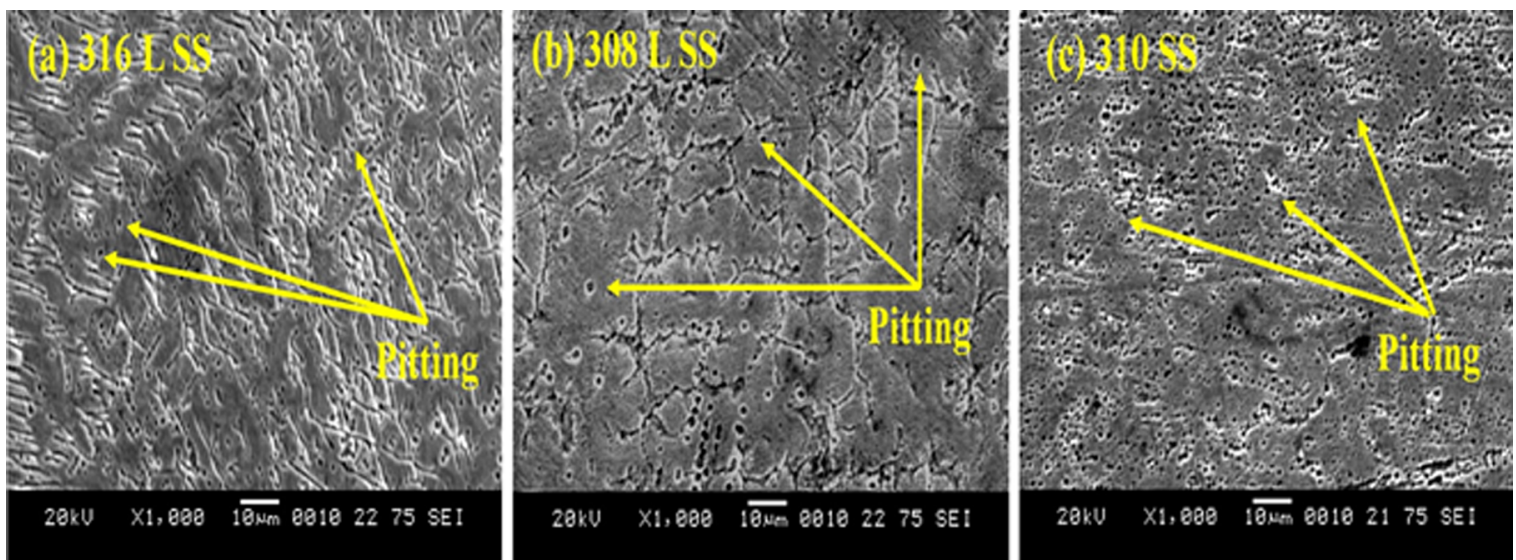

Figure 9. Pitting micrograph after polarization of weld zone (a) 316L SS (b) 308L SS (c) 310 SS 


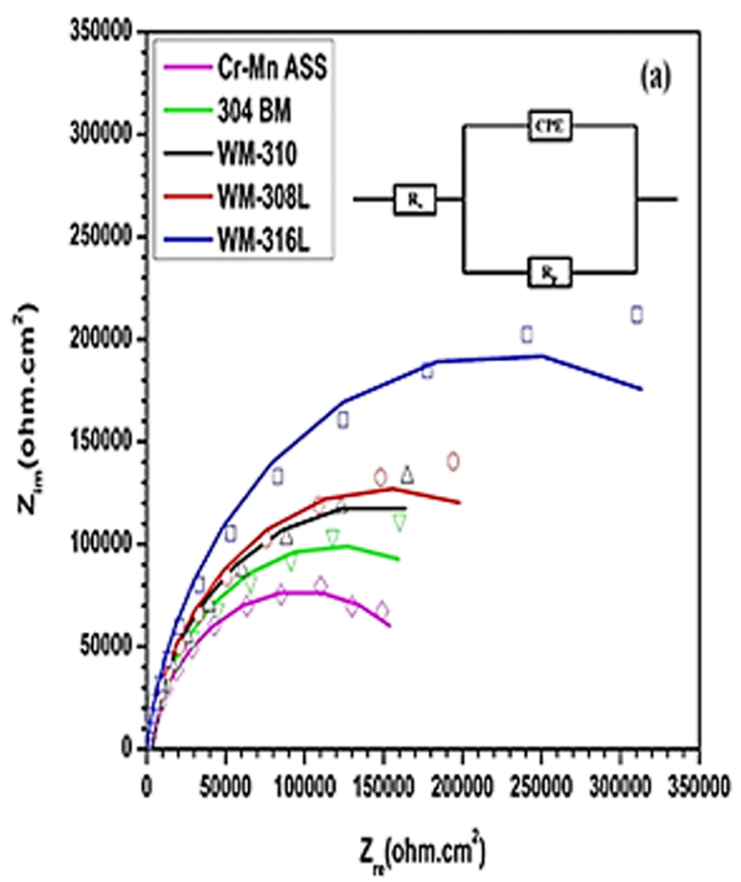

(a) Nyquist plot

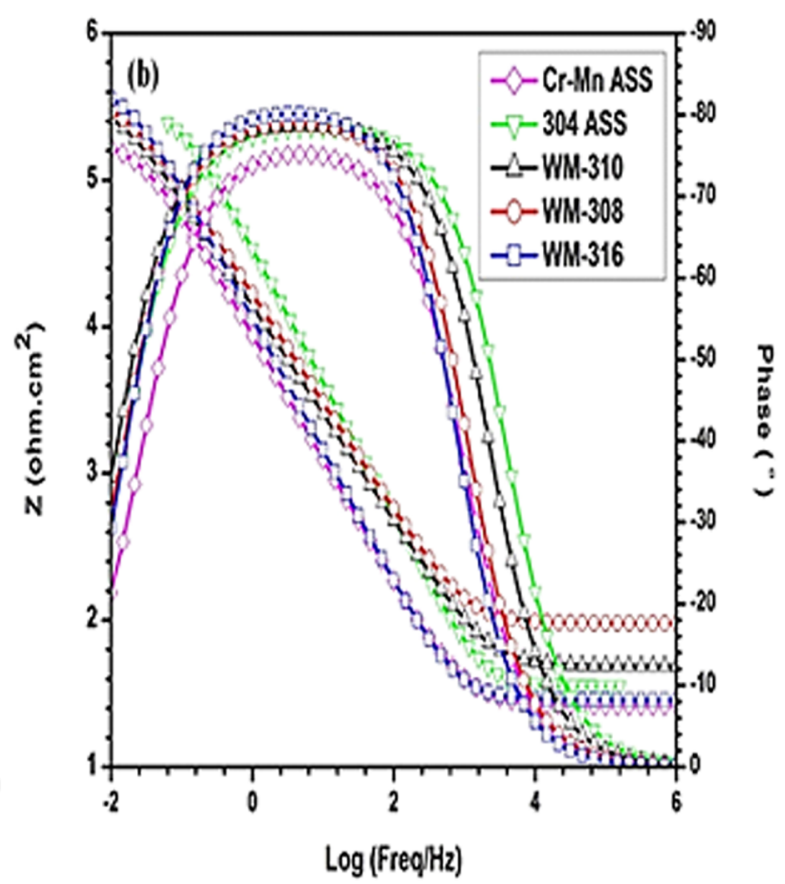

(b) Bode plot

Figure 10. Electrochemical impedance spectroscopy of various specimen (a) Nyquist plot (b) Bode plot

Table 7. Nyquist data after curve fitting

\begin{tabular}{|c|c|c|c|c|}
\hline Samples & $\underset{\substack{\mathbf{R}_{\text {sol }} \\
\left(\mathbf{o h m} . \mathrm{cm}^{2}\right)}}{ }$ & $\begin{array}{c}\text { CPE } \\
\left(\mu \mathrm{F} \cdot \mathrm{cm}^{2}\right)\end{array}$ & n & $\underset{\substack{R_{p} \\
\left(o h m . c^{2}\right)}}{ }$ \\
\hline Cr-Mn SS & 26.13 & 26.78 & 0.84 & 196017 \\
\hline $304 \mathrm{SS}$ & 4.56 & 31.35 & 0.87 & 240995 \\
\hline 316L SS & 28.59 & 16.65 & 0.90 & 451769 \\
\hline 308L SS & 14.91 & 26.37 & 0.88 & 304694 \\
\hline $310 \mathrm{SS}$ & 6.61 & 33.55 & 0.87 & 287419 \\
\hline
\end{tabular}

the Figure 10 (a) that smaller depressed semi-circle was found in Cr-Mn SS as compared to other samples. The $\mathrm{R}_{p}$ of welded samples was found to be least in $310 \mathrm{SS}$ and increases further for 308L and 316L samples. Therefore, the $316 \mathrm{~L}$ reflects the better passivation behavior as compared to rest of the samples. This may be due to higher $\mathrm{Cr}$, Mo and more $\delta$ ferrite in the weld metal. Figure 10 (b) shows Bode plot of different samples. One phase lag was observed in the middle of the frequency range ( $\log Z$ vs frequency). Also, phase angle below 90 degrees confirms the formation of a capacitive loop which is attributed to the formation of the passive films. The presence of Mo in $316 \mathrm{~L}$ helps to improve the corrosion resistance. The beneficial effect of Mo is due to the external film formed over the surface between metalsolution interface which limits the dissolution rate of $\mathrm{Fe}$ and $\mathrm{Cr}$ in the solution ${ }^{39,40}$.

\subsubsection{Galvanic coupling current density}

Figure 11 ( $a$ and $b$ ) shows the galvanic current density $\left(i_{\mathrm{G}}\right)$ of the base metals and their respective weld samples. It is observed that current density fluctuates with time also there are many transients. The value of $i_{\mathrm{G}}$ is shown in Table 8. It was found that $\mathrm{Cr}-\mathrm{Mn}$ SS coupled with all welded samples shows higher current density as compared to 304 SS. This may be due to the lower $\mathrm{Cr}$ content in the base metal than the weld electrodes. However, among all the welded samples coupled with both base metals, 316L filler weld showed highest $i_{\mathrm{G}}$ which is due to large the volume fraction of $\delta$-ferrite in the weld samples. The lowest $i_{\mathrm{G}}$ is observed for 310 weld and is attributed to similar phase structure (austenitic). The ascending order of the $i_{\mathrm{G}}$ is as follows.

Base metal- 310 weld $<$ Base metal- $308 \mathrm{~L}$ weld $<$ Base metal- 316L weld

\section{Conclusions}

1. The selected electrodes $316 \mathrm{~L}, 308 \mathrm{~L}$ and $310 \mathrm{SS}$ are suitable for defect free joining of dissimilar metals i.e. $304 \mathrm{SS}$ and $\mathrm{Cr}-\mathrm{Mn} \mathrm{SS}$.

2. The welded zone produced by $316 \mathrm{~L}$ and $308 \mathrm{~L}$ SS filler mainly consisted of austenite and $\delta$-ferrite in its microstructures. Whereas the microstructure 


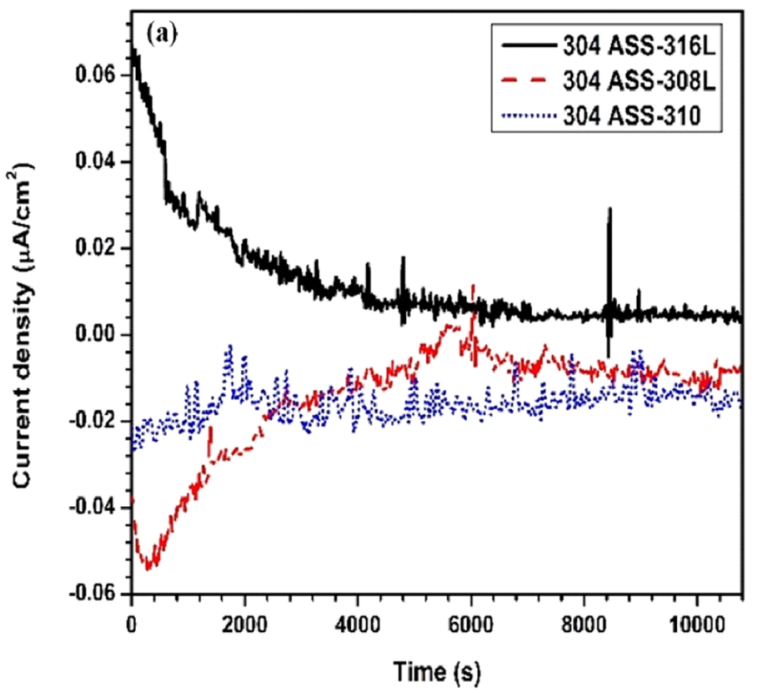

(a) $304 \mathrm{SS}$

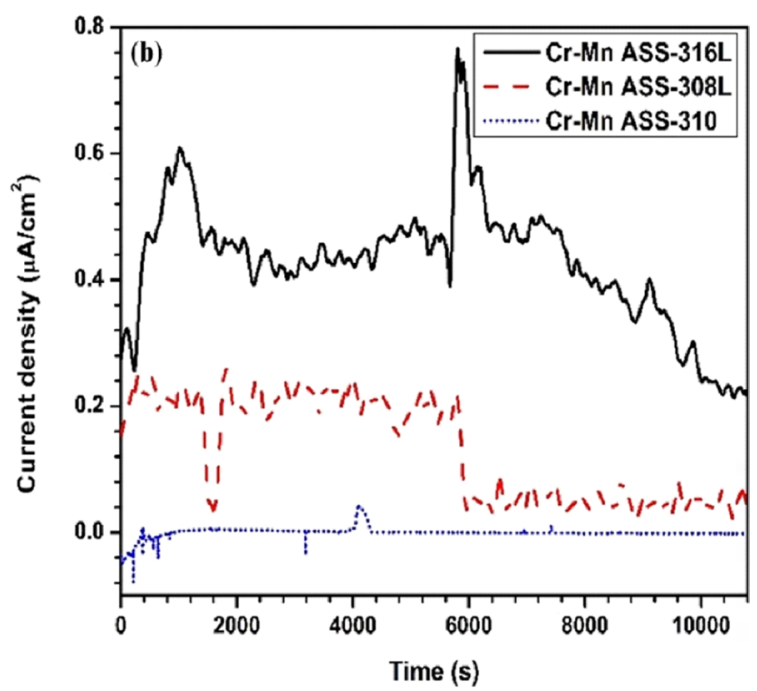

(b) Cr-Mn SS

Figure 11. Galvanic current density of (a) 304 SS (b) Cr-Mn SS coupled with various weld zone.

Table 8. Galvanic current density between 304 SS and Cr-Mn SS with different welded samples

\begin{tabular}{lc}
\hline Galvanic Coupling & $\begin{array}{c}\text { Galvanic current } \operatorname{density}\left(i_{\mathbf{G}}\right) \\
\mathbf{n A} / \mathbf{c m}^{2}\end{array}$ \\
\hline 304 SS-310 & -14.25 \\
304 SS-308L & -8.29 \\
304 SS-316L & 4.23 \\
Cr-Mn SS-310 & 2.29 \\
Cr-Mn SS-308L & 50.55 \\
Cr-Mn SS-316L & 401.7 \\
\hline
\end{tabular}

developed by 310 SS electrode showed cellular structure.

3. In the weld zone, high hardness was observed in sample welded with $316 \mathrm{~L}$ SS followed by $308 \mathrm{~L}$ and 310 SS. Tensile specimen was fractured at 304 $\mathrm{SS}$ side of the weld. This indicates weld is stronger than the base metal.

4. The higher pitting potential was observed in $316 \mathrm{~L}$ SS followed by $308 \mathrm{~L}$ and $310 \mathrm{SS}$. This is due to the beneficial effect of Mo and more $\delta$ ferrite in the weld zone causing better corrosion resistance in $3.5 \% \mathrm{NaCl}$ solution.

5. Electrochemical impedance spectroscopy revels larger polarization resistance in $316 \mathrm{~L} \mathrm{SS}$. This is due to the beneficial effect of molybdenum in the passive film and also more $\delta$-ferrite in the weld zone helps in forming passive films.

6. Large galvanic current density was observed in the sample coupled with Cr-Mn SS and weld zones as compared to $304 \mathrm{SS}$ coupled with different weld zone.

\section{Acknowledgment}

The authors are thankful to Mr. Shreedhar Gadge (Senior Technician, Chemical Analysis Laboratory, Department of Metallurgical and Materials Engineering) for performing the solution annealing treatment and Mr. Ventak Raman (Sr. Plant Manager, Ador Fontech Ltd.) for proving welding facility.

\section{References}

1. Karjalainen LP, Taulavuori T, Sellman M, Kyröläinen A. Some Strengthening Methods for Austenitic Stainless Steels. Steel Research International. 2008;79(6):404-412.

2. Padilha AF, Plaut RL, Rios PR. Annealing of Cold-worked Austenitic Stainless Steels. ISIJ International. 2003;43(2):135-143.

3. Khobragade NN, Khan MI, Patil AP. Corrosion Behaviour of Chrome-Manganese Austenitic Stainless Steels and AISI 304 Stainless Steel in Chloride Environment. Transactions of the Indian Institute of Metals. 2013;67(2):263-273.

4. Verma J, Taiwade RV. Dissimilar welding behavior of $22 \% \mathrm{Cr}$ series stainless steel with $316 \mathrm{~L}$ and its corrosion resistance in modified aggressive environment. Journal of Manufacturing Processes. 2016;24(Pt 1):1-10.

5. Bansod AV, Patil AP, Moon AP, Khobragade NN. Intergranular Corrosion Behavior of Low-Nickel and 304 Austenitic Stainless Steels. Journal of Materials Engineering and Performance. 2016;25(9):3615-3626.

6. Fajardo S, Bastidas DM, Criado M, Bastidas JM. Electrochemical study on the corrosion behaviour of a new low-nickel stainless steel in carbonated alkaline solution in the presence of chlorides. Electrochimica Acta. 2014;129:160-170.

7. ASSDA. 200 Series Stainless Steel Cr-Mn Grades. Brisbane: ASSDA; 2006. p. 1-3. 
8. Vashishtha H, Taiwade RV, Sharma S, Patil AP. Effect of welding processes on microstructural and mechanical properties of dissimilar weldments between conventional austenitic and high nitrogen austenitic stainless steels. Journal of Manufacturing Processes. 2017;25:49-59.

9. Verma J, Taiwade RV, Khatirkar RK, Kumar A. A Comparative Study on the Effect of Electrode on Microstructure and Mechanical Properties of Dissimilar Welds of 2205 Austeno-Ferritic and 316L Austenitic Stainless Steel. Materials Transactions. 2016;57(4):494-500.

10. Das CR, Bhaduri AK, Srinivasan G, Shankar V, Mathew S. Selection of filler wire for and effect of auto tempering on the mechanical properties of dissimilar metal joint between 403 and 304L(N) stainless steels. Journal of Materials Processing Technology. 2009;209(3):1428-1435.

11. Ramkumar KD, Oza S, Periwal S, Arivazhagan N, Sridhar R, Narayanan S. Characterization of weld strength and toughness in the multi-pass welding of Inconel 625 and Super-duplex stainless steel UNS S32750. Ciência \& Tecnologia dos Materiais. 2015;27(1):41-52.

12. Pujar MG, Dayal RK, Malhotra SN, Gill TPS. Dissolution behaviour of stainless steel weld metals during active potential range: a calculational approach. Journal of Materials Science. 2000;35(3):735-746.

13. Vitek JM, David SA, Hinman CR. Improved Ferrite Number Prediction Model that accounts for Cooling Rate Effects-Part 1: Model Development. Welding Research. 2003;82:10-17.

14. Kain V, Chandra K, Adhe KN, De PK. Effect of cold work on low-temperature sensitization behaviour of austenitic stainless steels. Journal of Nuclear Materials. 2004;334(2-3):115-132.

15. Lundin CD, Chou CPD, Sullivan CJ. Hot Cracking Resistance of Austenitic Stainless Steel Weld Metals. Welding Research Supplement. 1980;12:226s-232s.

16. Rahmani M, Eghlimi A, Shamanian M. Evaluation of Microstructure and Mechanical Properties in Dissimilar Austenitic/Super Duplex Stainless Steel Joint. Journal of Materials Engineering and Performance. 2014;23(10):3745-3753.

17. Mittal R, Singh BS. Microstructures and mechanical properties of dissimilar T91/347H steel weldments. Journal of Materials Processing Technology. 2015;220:76-86.

18. Yazdian N, Mohammadpour M, Razavi R, Kovacevic R. Hybrid laser/arc welding of 304L stainless steel tubes, part 2 - Effect of filler wires on microstructure and corrosion behavior. International Journal of Pressure Vessels and Piping. 2018;163:45-54.

19. Vashishtha H, Taiwade RV, Khatirkar RK, Dhoble AS. Effect of austenitic fillers on microstructural and mechanical properties of ultra-low nickel austenitic stainless steel. Science and Technology of Welding and Joining. 2016:21(4):331-337.

20. Kianersi D, Mostafaei A, Ali AA. Resistance spot welding joints of AISI 316L austenitic stainless steel sheets: Phase transformations, mechanical properties and microstructure characterizations. Materials \& Design. 2014;61:251-263.
21. Terada M, Escriba DM, Costa I, Materna-Morris E, Padilha AF. Investigation on the intergranular corrosion resistance of the AISI $316 \mathrm{~L}(\mathrm{~N})$ stainless steel after long time creep testing at $600{ }^{\circ} \mathrm{C}$. Materials Characterization. 2008;59(6):663-668.

22. Kumar S, Shahi AS. Effect of heat input on the microstructure and mechanical properties of gas tungsten arc welded AISI 304 stainless steel joints. Materials \& Design. 2011;32(6):36173623 .

23. Wang S, Ma Q, Li Y. Characterization of microstructure, mechanical properties and corrosion resistance of dissimilar welded joint between 2205 duplex stainless steel and $16 \mathrm{MnR}$. Materials \& Design. 2011;32(2):831-837.

24. McCafferty E. Validation of corrosion rates measured by the Tafel extrapolation method. Corrosion Science. 2005;47(12):32023215 .

25. Kokawa H, Kuwana T, Yamamoto A. Crystallographic Characteristics of Delta-Ferrite Transformations in a 304L Weld Metal at Elevated Temperatures. Welding Research Supplement. 1989;68:92S-101S.

26. Inoue H, Koseki T, Ohkita S, Fuji M. Formation mechanism of vermicular and lacy ferrite in austenitic stainless steel weld metals. Science and Technology of Welding and Joining. 2000;5(6):385-396.

27. Sumita M, Hanawa T, Teoh SH. Development of nitrogencontaining nickel-free austenitic stainless steels for metallic biomaterials-review. Materials Science and Engineering: $C$. 2004;24(6-8):753-760.

28. Sabooni S, Karimzadeh F, Enayati MH, Ngan AHW, Jabbari $\mathrm{H}$. Gas tungsten arc welding and friction stir welding of ultrafine grained AISI 304L stainless steel: Microstructural and mechanical behavior characterization. Materials Characterization . 2015;109:138-151.

29. Sathiya P, Kumar Mishra M, Soundararajan R, Shanmugarajan B. Shielding gas effect on weld characteristics in arc-augmented laser welding process of super austenitic stainless steel. Optics \& Laser Technology. 2013;45:46-55.

30. Ibrahim MAM, El Rehim SSA, Hamza MM. Corrosion behavior of some austenitic stainless steels in chloride environments. Materials Chemistry and Physics. 2009;115(1):80-85.

31. Tsutsumi Y, Nishikata A, Tsuru T. Pitting corrosion mechanism of Type 304 stainless steel under a droplet of chloride solutions. Corrosion Science. 2007;49(3):1394-1407.

32. Sun GF, Zhang YK, Zhang MK, Zhou R, Wang K, Liu CS, et al. Microstructure and corrosion characteristics of 304 stainless steel laser-alloyed with Cr-CrB2. Applied Surface Science. 2014;295:94-107.

33. Kang DH, Lee HW. Study of the correlation between pitting corrosion and the component ratio of the dual phase in duplex stainless steel welds. Corrosion Science. 2013;74:396-407.

34. Hamdy AS, El-Shenawy E, El-Bitar T. Electrochemical Impedance Spectroscopy Study of the Corrosion Behavior of Some Niobium Bearing Stainless Steels in 3.5\% NaCl. International Journal of Electrochemical Science. 2006;1(4):171-180. 
35. Silva CC, Miranda HC, Sant'Ana HB, Farias JP. Austenitic and ferritic stainless steel dissimilar weld metal evaluation for the applications as-coating in the petroleum processing equipment. Materials \& Design. 2013;47:1-8.

36. Gollapudi S. Grain size distribution effects on the corrosion behaviour of materials. Corrosion Science. 2012;62:90-94.

37. Jiang S, Chai F, Su H, Yang C. Influence of chromium on the flow-accelerated corrosion behavior of low alloy steels in $3.5 \% \mathrm{NaCl}$ solution. Corrosion Science. 2017;123:217-227.
38. Vijay P, Upadhyaya A. Evaluation of corrosion response of sintered ferritic stainless steels using potentiodynamic polarization and electrochemical impedance spectroscopy techniques. Transactions of the Indian Institute of Metals. 2008;61(2-3):255-259.

39. Kocijan A, Donik C, Jenko M. Electrochemical and XPS studies of the passive film formed on stainless steels in borate buffer and chloride solutions. Corrosion Science. 2007;49(5):2083-2098.

40. Hashimoto K, Asami K, Kawashima A, Habazaki H, Akiyama E. The role of corrosion-resistant alloying elements in passivity. Corrosion Science. 2007;49(1):42-52. 